\title{
Biogas as a Transport Fuel-A System Analysis of Value Chain Development in a Swedish Context
}

\author{
Muhammad Arfan *, Zhao Wang, Shveta Soam and Ola Eriksson (1D \\ Department of Building Engineering, Energy Systems and Sustainability Science, University of Gävle, \\ SE-801 76 Gävle, Sweden; Zhao.Wang@hig.se (Z.W.); Shveta.Soam@hig.se (S.S.); Ola.Eriksson@hig.se (O.E.) \\ * Correspondence: Muhammad.Arfan@hig.se; Tel.: +46-704-400-593
}

check for updates

Citation: Arfan, M.; Wang, Z.; Soam, S.; Eriksson, O. Biogas as a Transport Fuel-A System Analysis of Value Chain Development in a Swedish Context. Sustainability 2021, 13, 4560. https://doi.org/10.3390/su13084560

Academic Editors: Bacenetti Jacopo and Michele Costantini

Received: 24 March 2021

Accepted: 17 April 2021

Published: 20 April 2021

Publisher's Note: MDPI stays neutral with regard to jurisdictional claims in published maps and institutional affiliations.

Copyright: (C) 2021 by the authors Licensee MDPI, Basel, Switzerland. This article is an open access article distributed under the terms and conditions of the Creative Commons Attribution (CC BY) license (https:/ / creativecommons.org/licenses/by/ $4.0 /)$.

\begin{abstract}
Biofuels policy instruments are important in the development and diffusion of biogas as a transport fuel in Sweden. Their effectiveness with links to geodemographic conditions has not been analysed systematically in studying biogas development in a less urbanised regions, with high potential and primitive gas infrastructure. One such region identified is Gävleborg in Sweden. By using value chain statistics, interviews with related actors, and studying biofuels policy instruments and implications for biogas development, it is found that the policy measures have not been as effective in the region as in the rest of Sweden due to different geodemographic characteristics of the region, which has resulted in impeded biogas development. In addition to factors found in previous studies, the less-developed biogas value chain in this region can be attributed particularly to undefined rules of the game, which is lack of consensus on trade-off of resources and services, unnecessary competition among several fuel alternatives, as well as the ambiguity of municipalities' prioritization, and regional cultural differences. To strengthen the regional biogas sector, system actors need a strategy to eliminate blocking effects of identified local factors, and national policy instruments should provide mechanisms to process geographical conditions in regulatory, economic support, and market formation.
\end{abstract}

Keywords: biogas; transport; value chain; policy instruments; system analysis

\section{Introduction}

Globally the transport sector is one of the major sources contributing to greenhouse gases (GHG) emission and requires an urgent transition from fossil to renewable fuels to mitigate climate change. The GHG emissions from the Swedish road transport sector were $16.5 \mathrm{Mt} \mathrm{CO}_{2}$-eq. in 2018. This was approximately $79 \%$ of the total GHG emissions from domestic transport and $32 \%$ of national GHG emissions excluding land use, land-use change, and forestry (LULUCF). The increase in the net GHG emissions from road transport in 2018 was $4.1 \%$ since 1990 . To mitigate environmental problems, several policies and targets have been set by the European Union (EU) and its member states together with different measures to achieve these goals. In Sweden, the share of renewables in transport was $22 \%$ in 2017 [1], which had already crossed the EU mandate of $20 \%$ by 2020 . (Measured by energy content. The directive allows for double counting of transport biofuels that are produced from residues or waste. In Sweden, the use of biogas and HVO produced from waste and residues is thus double counted, resulting in a higher value compared to the share of renewables measured by energy content. Counting as specified in the directive ) However, the Swedish government has set ambitious targets for the transport sector such as a fossil-independent vehicle fleet by 2030 and zero net GHG emissions by 2045 [2]. To achieve these targets, one measure among others is to increase the use of different renewable fuels in the transport sector. For instance, biogas is a promising renewable transport fuel with production reached 2.1 TWh by 2017 and offers significant environmental, economic, and social benefits $[3,4]$. 
Biofuel development, in general, is dependent on many factors such as technical, economic, and political. The effect of policy incentives on the growth of biofuels has already been studied by many authors [5-7]. Biofuels and policy literature represent different geography and have analysed the subject from different perspectives. Some authors [8-10] have analysed the national policy and other factors impacts the expansion of different biogas systems in the Netherlands, Ireland, and Sweden. They emphasised that policies, in the long run, should focus on increasing incentives for all biogas value chain segments simultaneously. They also suggested that the policy measures should facilitate the introduction of biogas to the captive fleet, injection to the gas grid, and feed-in tariff regulation. Other studies, such as [11-15], identified different types of barriers to biogas development and use in transport from a national perspective in different EU member states. They found uncertainties regarding feedstock and fuel supply security, limited infrastructure, and higher costs of alternative fuels and vehicles as significant factors limiting biogas development. The recent studies $[1,7,16-18]$ on policies, incentives, and barriers for biogas development and use in transport from regional perspectives in Sweden focused on well-developed and densely populated areas (i.e., Stockholm, Linköping, Skåne etc.) having a long history of gas infrastructure and related developments. According to these studies, national biogas policy directions and incentive programs are powerful tools, but regional development is mostly dependent on specific local characteristics. Further, Gustafsson and Mignon [19], write that municipalities act as intermediate bodies in translating the national vision and their strategies are highly influenced by local circumstances and guided by local experiments, rather than central governance systems and national policies. Thus, subnational/regional boundary should be considered in understanding the additional factors and policy issues that constraint biogas development as transport fuels in a specific region of Sweden. Such analysis can also facilitate understanding what actors at the regional level (including policymakers) can achieve by themselves and what can be built on through an exogenous system (e.g., external support and policies).

Although the 'geographical characteristics turn' is well persuasive in biogas literature on development and barriers, there is no study available that has systematically analysed the influence of biofuels policy instruments and geodemographic characteristics on biogas as a transport fuel in a less urbanised region with scattered population and primitive gas infrastructure such as Gävleborg in Sweden. The Gävleborg region is utilizing only around $10 \%$ of its total theoretical biogas potential (excluding forest biomass) [20]. For this region and other regions with similar geodemographic characteristics, there is a need to understand why the existing biogas potential has not been utilised. Therefore, this paper aims to fill the highlighted knowledge gap by identifying and analysing the role of the most relevant national biofuels policy instruments and geodemographic characteristics to the biogas value chain development in the Gävleborg region. To fully address the aim of this study, the following research questions are to be answered:

1. How has biogas evolved as transport fuel in Gävleborg compared to rest of Sweden?

2. What regional geodemographic characteristics have restricted biogas development in Gävleborg?

3. What lessons can be learnt to expand biogas as a transport fuel in Gävleborg and similar regions?

Towards that end, the system under study, strategy for data collection and analysis are described first. Following these, analysis of Swedish biofuels policy instruments implications to biogas as a transport fuel, the biogas development over time and along the value chain in Gävleborg are statistically presented and compared with the biogas development in the rest of Sweden. Subsequently, the factors affecting biogas development in the region and suggestions on actions to build on existing strengths and to eliminate negative factors for further development of biogas as a transport fuel in Gävleborg and other similar regions are discussed. 


\section{Materials and Methods}

The regional biogas development is a complex phenomenon that could be influenced by several factors ranging from inter-correlation of the various segments of the value chain, actors, policy, and geodemography. In Figure 1, a conceptualised model of this complexity is provided by illustrating the system under study.

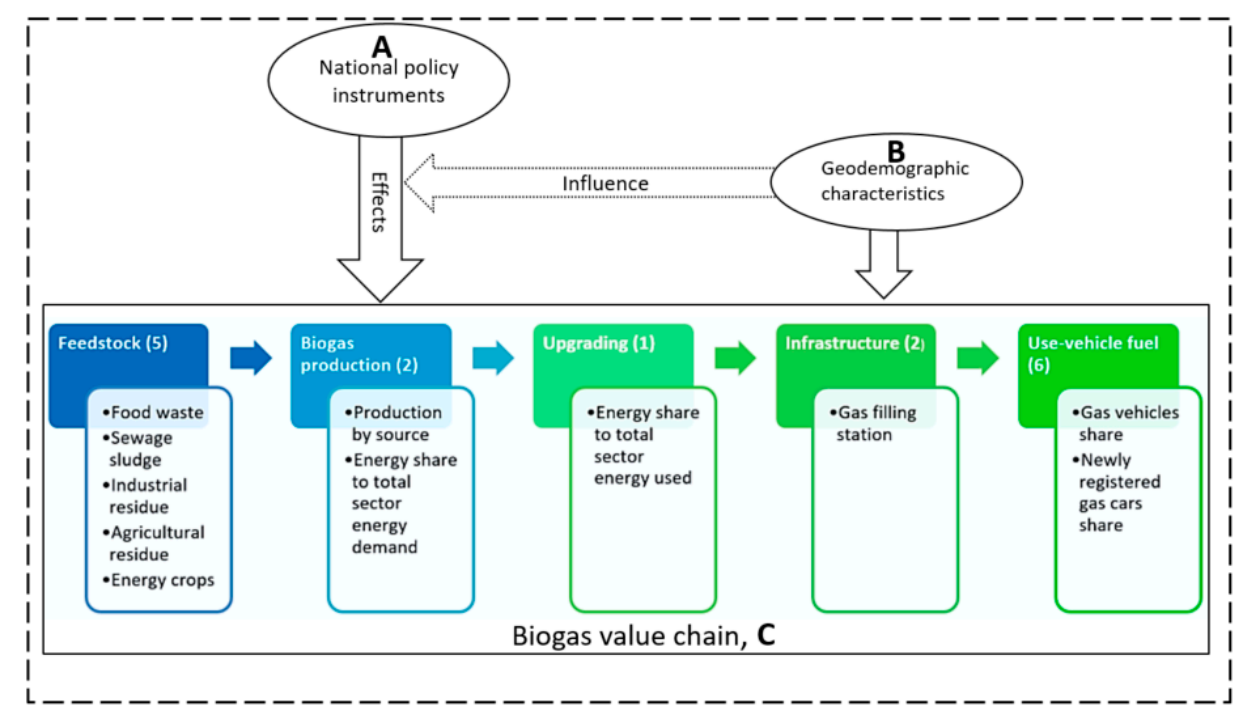

Figure 1. System under study. Numbers in parenthesis represent the number of companies interviewed in the respective segment.

\subsection{System Description}

This study focuses on a regional biogas value chain (i.e., Gävleborg region (The focus geographical area is Gävleborg region that is located in central Sweden on the Baltic Sea coast and consists of 10 municipalities with 286,399 inhabitants. Source: www.scb.se (accessed on 2 June 2017))) whose current status and future development is analysed concerning policy implications as well as influence from the geodemographic conditions (see Figure 1). Value chain assessment is a simple but powerful tool to identify actors, resource flow, and system product applications [21]. This concept is applied to understand the biogas development in the region by identifying actors, feedstocks, technologies, and biogas use as a fuel in the transport sector. The feedstocks considered are sewage sludge, organic fraction of municipal solid waste (OFMSW), industrial organic residues, agricultural residues, and energy crops. The technology is anaerobic digestion (AD) that is widely used in operation in Sweden and in this region to produce biogas. Before its end use as a transport fuel, biogas is upgraded to bio-methane and distributed by either road or pipeline to filling stations.

In Figure 1, the policy part (circle A) represents various instruments that can be directed to influence different segments of the biogas value chain $(C)$. The impact of biofuels policy instruments on the biogas development could also be influenced by several other factors such as the regional geodemographic characteristics (circle B) [19]. More specifically, as shown in Figure 1 the dotted arrow symbolises the influence on national policy instruments from geodemographic characteristics where local factors such as landscape, political environment and vision, regional targets, and strategies for transport, etc., can be included. On the other hand, the solid arrow represents the direct influences on the biogas value chain. In the value chain $(C)$, filled colored boxes indicate value chain segments and numbers in parenthesis represent the number of companies interviewed in the respective segment. The details on the organizations and interviewees of each segment are given in Appendix A. Associated with each segment, different indicators used for statistical analysis of that specific value chain segment are provided within the uncolored boxes. 


\subsection{Data Collection and Analysis}

Based on the nature of the research questions, different methods including literature study, statistical analysis, and interviews with regional value chain actors were deployed. The statistics mostly obtained from published reports by Swedish Energy Agency (SEA) and Statistics Sweden (SCB) were compiled to analyse the actual development in the region as well as in Sweden. The implications of different policy instruments to biogas development are summarised based on published material (i.e., articles and research reports). Interviews with the target groups were conducted to identify the regional geodemographic factors and policy's role in biogas development in the region. Other aspects that were regarded as prerequisites (such as infrastructure, legitimacy, political beliefs, etc.) for a regional biogas expansion were also discussed. Initially, twenty actors/organizations were identified as important players and approached through emails and phone calls to check the availability of the most relevant person(s) and their willingness to participate in an interview. The selection of the participating organizations was made to ensure that the whole value chain was covered, and the organizations have some form of function in relation to biogas activities in the region. Fourteen organizations participated in the interview process; brief information about the organization and the respondents are listed in Appendix A Table A1. The other six organizations, due to the unavailability of suitable resources, did not participate.

The interviews with the regional biogas value chain actors were conducted during 2018 and 2019 and lasted between 1 and 2 hrs each. An approach called "responsive interviewing" was used [22]. This approach "relies heavily on the interpretive constructionist philosophy, mixed with a bit of critical theory, and then shaped by the practical needs of doing interviews" (ibid). Interviews were preferred over questionnaires because some questions required elaboration from some of the actors involved. The interview questions can be divided into three types: main questions, follow-up questions and probes. The main questions were designed to focus on the research problem (i.e., what is lacking?) and to stay on target with addressing the research puzzle. The follow-up and probe questions were asked to ensure that we pursued depth, detail, vividness, richness, and nuance. The focus was on the research questions, but there was also room for each respondent to elaborate on issues they considered challenging and important. The interview questions were prepared using the key terms policies, support schemes, regulations, influencing factors outside national policies and regulations, and actions required for biogas expansion as a transport fuel in the region. Some sample interview questions are given in Appendix B.

\section{Policy Instruments and Implications to Biogas}

The national policy instruments on biofuels development are assumed as politically derived tools that can be applied to different segments of the biofuels value chain to influence its development. These instruments can be categorised as economic, fiscal, regulatory, information, and research, development, and demonstration (RD\&D) [23]. The fiscal, economic and regulatory policy instruments have been regarded as the most powerful and effective ones in developing the biofuel industry and market for alternative transport fuels in Sweden [24-26]. Table 1 summarises the fiscal, regulatory, and economic instruments that are related to biofuels development for transport in Sweden, and their implications to biogas value chain based on peer-reviewed scientific literature mainly.

It is difficult to differentiate the effect of an individual policy instrument due to the overlap of different instruments in time and continuation of a programme in a different form as well as from other factors on biogas development. It is a complex situation and there could be synergetic effects of a combination of different instruments. For example, energy and $\mathrm{CO}_{2}$ tax exemptions for biofuels reduce prices and make the fuels competitive with fossil fuels, while the same type of tax on fossil fuels creates a market for biofuels through the blend-in option. Another point is the period when considering the policy instruments for effect analysis; often there is a time lag of one to four years between an investment decision and the production start for a complete biogas facility [11]. If initial planning time 
is also considered, this time lag could be six to eight years. Thus, it is reasonable to consider a policy instrument available six to eight years back, such as the climate investment program (KLIMP), from the starting year of statistical analysis. The implications of policy instruments (Table 1) indicate that the measures have had more focus on market i.e., use of biogas or biofuels as vehicle fuel than other segments. For example, higher tax exemption benefits biogas as transport fuel, green vehicles rebate, public procurement, and support for renewable fuel supply have incentive the use as vehicle fuel segment of the value chain.

Table 1. Swedish national policy instruments and measures with their implications for biogas in the transport sector.

\begin{tabular}{|c|c|c|c|}
\hline Type & Year (Start-End) & Policy Instrument Name & Implications \\
\hline \multirow{3}{*}{ Fiscal } & (2004-) & $\begin{array}{l}\text { Full energy and carbon tax } \\
\text { exemption for biofuels [27] }\end{array}$ & $\begin{array}{l}\text { It is considered as one of the most important policy } \\
\text { instruments in the introduction of renewable fuels in } \\
\text { Sweden. The combination of the instruments may } \\
\text { have synergy effects, but this instrument has been } \\
\text { the single most influential. It reduced the end price, } \\
\text { and thus made biogas use as transport fuel } \\
\text { competitive [11]. It has a lower effect on production } \\
\text { than on use segment [24]. }\end{array}$ \\
\hline & (2010-) & $\begin{array}{l}\text { Tax exemption for } \\
\text { environmentally friendly } \\
\text { vehicles [28] }\end{array}$ & $\begin{array}{l}\text { Influenced the choice of vehicles when } \\
\text { environmentally friendly technology is being } \\
\text { preferred. The choice is strongly connected to } \\
\text { financial incentives, fueling infrastructure, vehicle } \\
\text { technology and availability of different models and } \\
\text { their resale market value [7]. }\end{array}$ \\
\hline & (2011-) & $\begin{array}{l}\text { Energy and CO2 tax on fossil } \\
\text { fuels [27] }\end{array}$ & $\begin{array}{c}\text { It favoured renewable energy demand in general but } \\
\text { particularly the use of renewable fuels in the } \\
\text { domestic transport sector [29]. }\end{array}$ \\
\hline \multirow[t]{3}{*}{ Regulatory } & $(2002-)$ & $\begin{array}{l}\text { Ban on landfilling organic } \\
\text { materials and methane } \\
\text { collection [30] }\end{array}$ & $\begin{array}{c}\text { Favoured anaerobic digestion (AD) of organic waste } \\
\text { with energy recovery (e.g., biogas). In Sweden, in } \\
\text { 2011, 24\% of municipal food waste was treated in } \\
\text { AD with biogas production while in 2016-2017, it } \\
\text { was } 35 \% \text {. Lower incentives for related infrastructure } \\
\text { development needs to be made expensive in some } \\
\text { municipalities and acted as a barrier to break the } \\
\text { lock-in effect of conventional waste treatment } \\
\text { methods, i.e., incineration }[10,11,29] .\end{array}$ \\
\hline & $(2006-)$ & $\begin{array}{l}\text { Requirements of renewable } \\
\text { fuels at filling stations [31] }\end{array}$ & $\begin{array}{l}\text { In general, this instrument has been very effective in } \\
\text { improving biofuel infrastructure in Sweden but not } \\
\text { so effective for the regions with no natural gas } \\
\text { network and biogas production. About } 57 \text { new } \\
\text { vehicle gas filling stations were constructed between } \\
2007 \text { and } 2010 \text { and by the end of } 2017 \text {; there were } \\
185 \text { vehicle gas pumps in Sweden }[7,24]\end{array}$ \\
\hline & (2009-) & Green public procurement [32] & $\begin{array}{l}\text { The instrument improved the knowledge and } \\
\text { experience of companies and municipalities on } \\
\text { mechanisms of diffusion of new technology. Proved } \\
\text { to be a successful tool in creating an early market for } \\
\text { alternative fuels and vehicles. Still, in many } \\
\text { municipalities, the public transport fleet is the main } \\
\text { buyer and user of biogas as a transport fuel }[7,29,33] \text {. }\end{array}$ \\
\hline
\end{tabular}


Table 1. Cont.

\begin{tabular}{ccc}
\hline Type & Year (Start-End) & Policy Instrument Name \\
\hline$(1998-2002)$ & Local Investment Programme \\
& (LIP) [34]
\end{tabular}

(2003-2008)

(2009-2020)

(2013-2020)

Economic
Climate Investment Programme (KLIMP) [35]

The Rural Development Programme 2009-2013 and 2014-2020 [37,38]

Investment support; production, infrastructure and use of biogas [32]

Local climate investment program [39]

Green car rebate [40]

Support for renewable fuels supply [32]

Super-green car rebate [40]

Lower benefit value on cars with advanced environmental technology [25]
A predecessor of KLIMP. Biogas infrastructure development programs also benefited in addition to production projects $[24,26]$.

KLIMP enabled municipalities and other local actors to receive financial support for projects that reduce

GHG emissions. Mature technologies benefited most because the most cost and emission reduction

efficient solutions were awarded. Supported several biogas plants, mainly large projects in which municipalities took an active part $[10,26]$. The grants have been given to 67 municipalities, seven municipal associations, five regional councils and four companies in Sweden [36].

Available only for farmers for climate emissions reduction projects. Due to limited subsidy (EUR 200,000 , or $30-50 \%$ of the investment), large-scale production of biogas from manure could not benefit, nor does it increase the incentives for actors outside the agricultural sector [11].

A powerful incentive, if given in sufficient amounts.

The program focused on support to novel technologies for demonstration projects. The effects of the program on biogas production and use were limited due to the very low support premium [10]. Several biogas plants and infrastructure projects, e.g., gas filling stations received support [25]. Most cost-effective and mature technology solutions were awarded [24].

The instrument did not affect the biogas market much due to the very low premium $[7,26]$.

An important incentive that significantly increased the number of renewable fuel filling stations.

However, the impact of the program was smaller than expected on biogas infrastructure development due to issues regarding the supply and demand of biogas and vehicles as well as the structure of the grant [41].

This has a neutral effect on the biogas passenger car market but increased the drive of the introduction of electric technology and vehicles. Boosts the green vehicle technology debate that influenced individuals and companies $[7,24,26]$.

Benefits companies in car leasing business and taxi.

There has been very little impact on the biogas market $[7,26]$.

\section{Results-Value Chain Development}

\subsection{Feedstock}

Figure 2 shows the share of different feedstocks for biogas production in Gävleborg as well as the rest of Sweden. This is not limited to biogas production used in the transport sector, but rather total raw biogas produced in Gävleborg and the rest of Sweden. The purpose here is not to show the amount of feedstock but rather to show the trend on different types of feedstock entered into the biogas production system over time. Sewage sludge from wastewater treatment plants has been the main feedstock for biogas production in both the Gävleborg region and Sweden. Since 2008, other feedstocks such as manure, food waste and industrial waste have increased on the national level (Figure 2a) but this was not the case in the region until the biogas plant (Forsbacka) started its operations in 2017 
with source-separated food waste as the main substrate. In 2018-2019, horse manure was added as a substrate during co-digestion (Figure 2b). It is worth highlighting here that this kind of feedstock for biogas production has been very limited in this region and development related to the installation of a biogas plant started very late. It is why other types of feedstocks were not used in the regional biogas production. From policy instruments implications perspective (Table 1), it is difficult to relate a specific policy instrument to the development of using other types of feedstocks for biogas production in Sweden and Gävleborg due to the complexity of the biogas system and synergetic effects of the different policy instruments. However, based on Table 1, the rural development program, KLIMP, and partially the ban on the landfill of organic waste can be assumed to play important roles in turning manure and food waste into the biogas production system in Sweden, but this argument does not seem valid for the Gävleborg region until 2017-2018, even if the feedstocks were available.

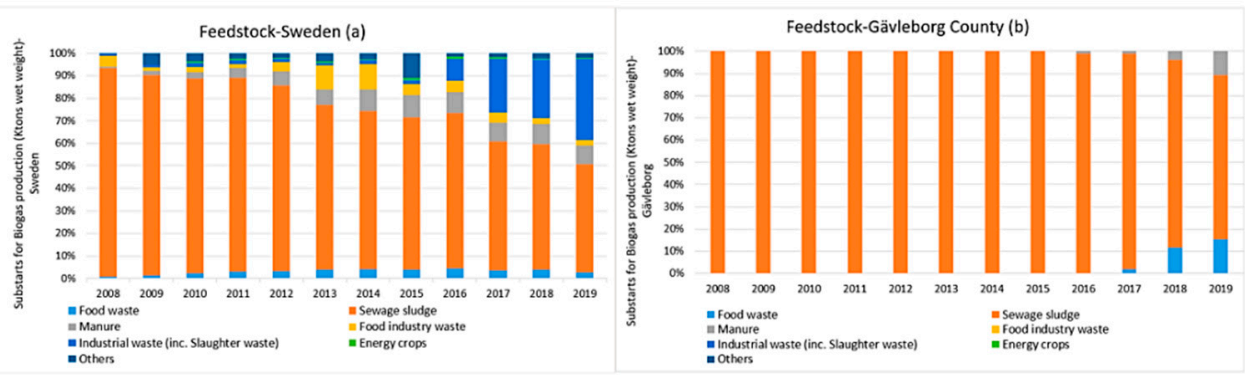

Figure 2. Feedstocks used for biogas production [(a): Sweden, (b): Gävleborg region] [42].

However, some actors during interviews mentioned that two projects (Biogas MellanNorrland (Biogas Mellannorrland AB was owned by three municipalities [Sundsvall, Östersund och Hudiksvall]. Hudiksvall is a municipality of Gävleborg Region. [https:// sundsvall.se/kommun-och-politik/overklaga-beslut-rattssakerhet/moten-och-protokoll/ bolag-och-forbund/biogas-mellannorrland-ab/] (accessed on 20 January 2021) and SETA) in the Gävleborg region received grants in 2011-2012 for producing biogas from manure and agricultural residue, but could not continue, predominantly due to higher biogas production costs, and longer transport distances and maintenance than for similar projects at other locations in Sweden. Forsbacka biogas plant in Gävle was partially funded by the local climate investment program. The plant has been designed to work with 25,000 tonnes of feedstock per year; however, in 2018 the plant was working with an average of 14,808 $\mathrm{t}$ /year correspond to the co-digestion of $80 \%$ of source-separated food waste from households and groceries, and $20 \%$ of green waste (Garden waste usually consists of tree branches, grass). Around $4.3 \%$ of the total input feedstock correspond to a semi-liquid residue such as food slurry/grease sludge collected from regional large kitchens and restaurants. Depending on the methane yield of the substrate, the plant at full capacity can produce 1.6-1.9 million $\mathrm{Nm}^{3} \mathrm{CH}_{4}$ gas per year, whereas the regional theoretical biogas production potential is around 23 million $\mathrm{Nm}^{3} \mathrm{CH}_{4}$ /year [20], which indicates that a lot more food waste, green waste, and food slurry/grease are available in the region than that used today.

\subsection{Production and Upgrading}

Until 2001, almost all biogas produced in Sweden was used for heat and electricity production [42]. However, after 2003, a combination of several policy instruments such as energy and $\mathrm{CO}_{2}$ tax, public procurement, green car rebate, renewable fuel supply, and emission reduction requirements on fossil fuels, etc. (Table 1), promoted biogas upgrading and use in transport. In 2017, around 64\% of the produced raw biogas in Sweden was upgraded and mainly used as a transport fuel [42]. In this section, we use 'share of biogas energy input to road transport sector energy demand' as an indicator to compare the development of biogas production and upgrading in the region in relation to the rest of Sweden. Here, it is also assumed that all the upgraded biogas is used as a transport fuel. 
It can be seen in Figure 3 that the development of regional biogas production is seemingly following the national trend. However, the share of upgraded biogas to the total sector energy demand has been almost zero in the region until 2010, mainly due to the lack of upgrading facilities. Even though biogas upgrading started in 2011, the share remained considerably lower (around $0.25 \%$ ) until the end of 2018 in the region compared to the national average $(1.75 \%)$. However, within 2019 , a sharp increase of about almost $80 \%$ (from 0.25 to 0.75 ) in the use of upgraded biogas as a transport fuel has happened in the Gävleborg region which should be linked to an increase in the number of biogas buses (around 40) in the public transport in Gävle. From this situation, it could be assumed that the biogas production and upgrading segments of the value chain in the region has been restricted by late municipalities decisions concerning public procurement of biogas-driven vehicles. Consequently, due to lower market demand in 2017-18, not all of the produced biogas in the region was upgraded; most often, the biogas not upgraded was flared. Furthermore, this lower market demand issue can also be attributed to gas filling station infrastructure and regional politics (see, Section 5). The programs (public procurement, tax on fossil fuels and exemption for biofuels) have been very successful in creating an upgraded biogas market in many parts of Sweden (Table 1), but the impact of these policy instruments in the region is constrained by the regional political decisions.

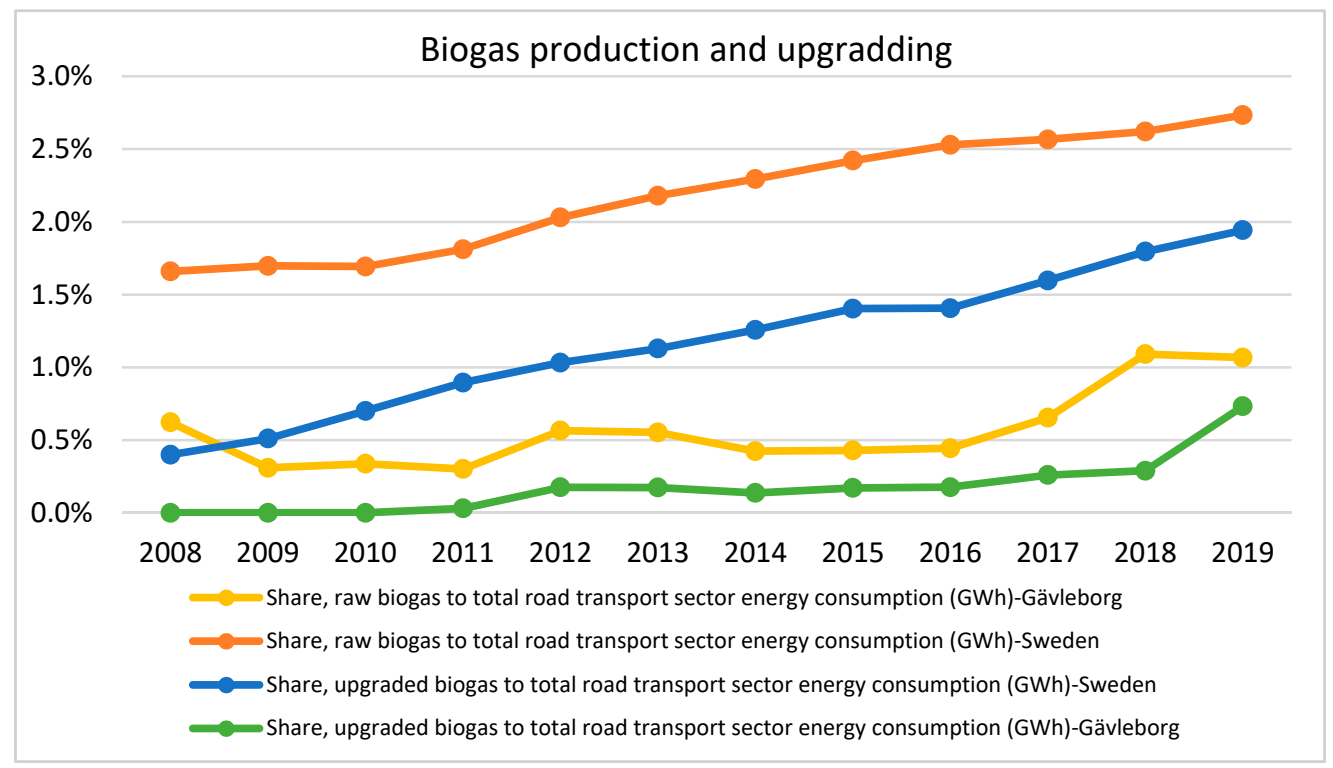

Figure 3. Share of raw and upgraded biogas to total transport sector energy consumption [42].

\subsection{Infrastructure}

For successful penetration of new vehicle fuel technology, filling stations should correspond to $5-20 \%$ of the number of conventional filling stations [11]. In 2017, there were 2970 petrol stations in Sweden and 250 gas stations (190 public and 60 non-public). (Non-public gas stations are mainly targeted at the private sector such as taxi companies. Bus filling stations are usually reserved for public transport buses, as they are the main user of biogas in Sweden. This categorization is to ensure security of supply, as not all filling stations are connected to the gas network.) Based on these statistics, the percentage of gas filling stations was $6.9 \%$ in Sweden, which is in the range of $5-20 \%$. However, the infrastructure situation varies greatly between regions. Regions with an existing gas network and high population density, particularly southern counties, have shown faster development in building gas infrastructure and creating market demand compared to northern counties having no prior gas infrastructure such as Gävleborg.

In Sweden, gas filling stations have continually increased over the last decade but this has not happened in the Gävleborg region (Figure 4). In the region, total gas filling stations (public and non-public) are two; the first one was built in 2010 at Gävle and the second in 
2017 at the Forsbacka biogas plant. Both are in the municipality of Gävle, implying that the remaining nine municipalities in the region have no gas filling stations. However, there is a plan to build more gas filling stations (around five) in the region by 2021-2022 (Personal communication with Eklund Öberg, Å. energy and climate coordinator, Gävleborg region administrative board (dated: 3 October 2019)). The policy instruments such as KLIMP, local climate investment, support for renewable fuel supply, etc., have shown great contributions to biogas infrastructure development in Sweden generally (Table 1), but this seems minor in the region.

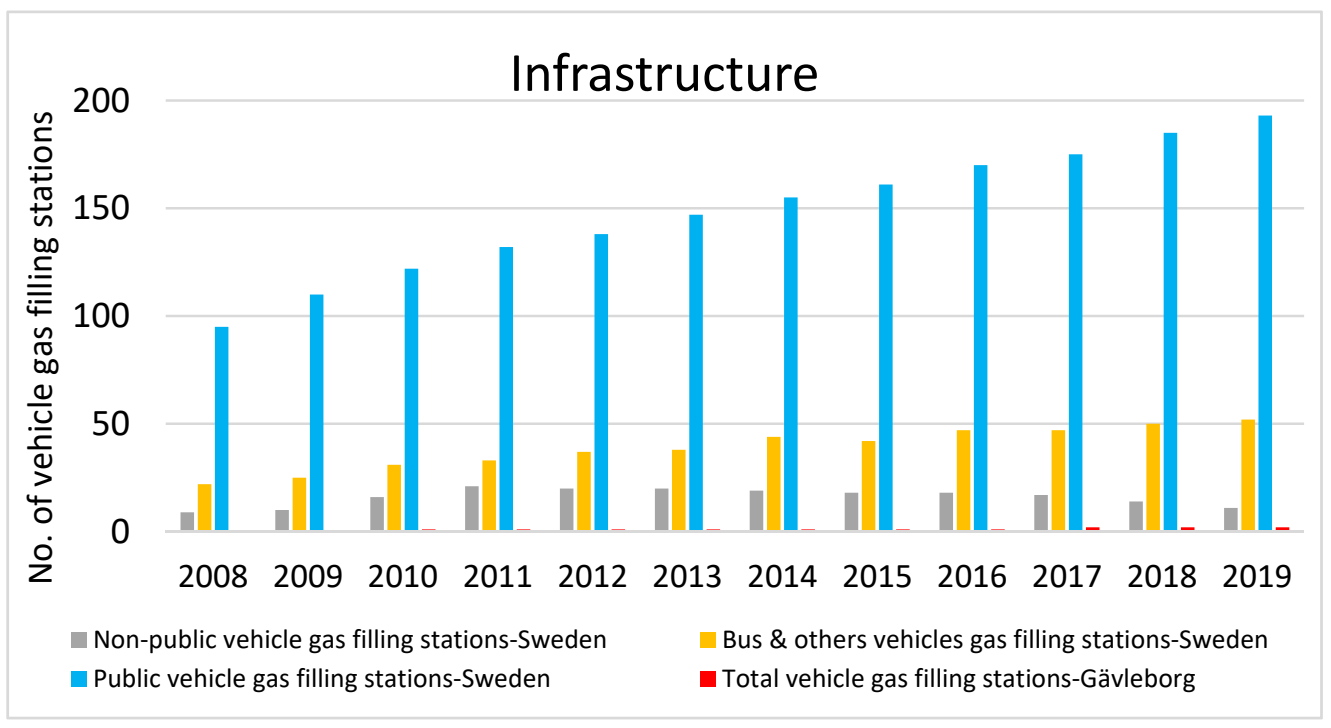

Figure 4. Vehicle gas filling stations [42].

\subsection{Use as a Vehicle Fuel}

The use of biogas buses in public transport in Sweden led to the early market formation for biogas as a transport fuel. This was further promoted through public procurement policy instrument [11]. In the Gävleborg region, initially, Gävle municipality introduced biogas as transport fuel with biogas buses in the public transport and biogas cars in the municipal vehicle fleet. Since 2010, the number of biogas buses remained around 40-45 until 2018 but this number has reached 90 in 2020 (this is based on the interview with Biodrivmitt and Xtrafik; official statistics were not updated), which is a big development in the region. The share of gas passenger cars in the region is five times lower than the national average. However, Figure 5 indicates that the gas cars have a better trend in Gävleborg than in Sweden as a whole. At least, the share of new gas cars sold has been quite stable compared to a decline on the national level. Passenger cars and buses (public transport) are the main users of vehicle gas, but interest in introducing liquefied vehicle gas for heavy-duty transport and shipping is developing fast in Sweden (Energy gas Sweden, 2019).

The gas cars in the region are mostly owned by the municipality of Gävle and organizations working for the municipality. There are some biogas trucks and cars at Sandviken probably due to the availability of gas filling stations at Forsbacka and Gävle city. The rest eight municipalities of the region have no gas vehicles. This could be because of many reasons but the most prominent ones are lack of gas filling stations and political support (see Section 6 for details). The green car rebate programs have shown a contribution to increased sale of gas and other green cars in Stockholm [11] and other regions in Sweden (Table 1). This might be the case in Gävle although the companies interviewed have had very less knowledge about the related policy instruments. 


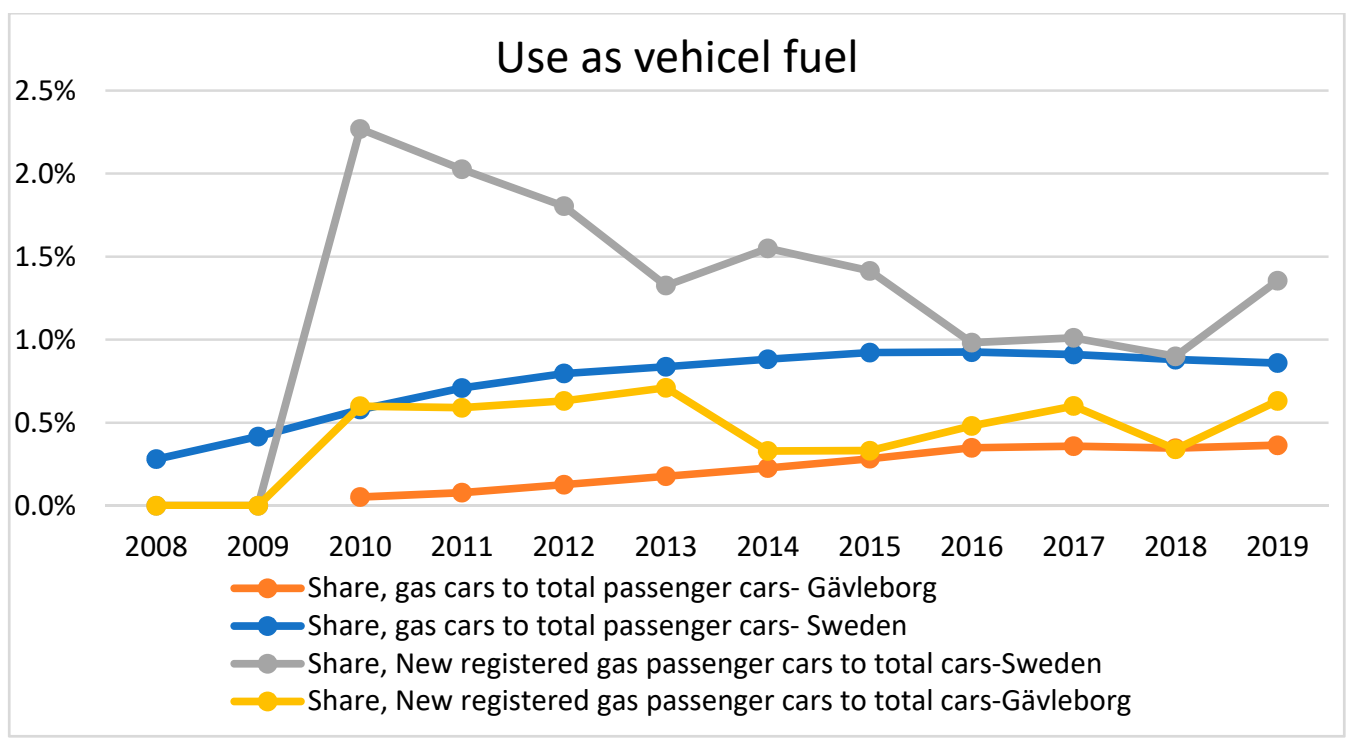

Figure 5. Existing and new registered gas passenger cars. Share, gas cars to total passenger cars shows gas cars stock on road compares to all other fuelled passenger cars on road each year. whereas, share, newly registered gas passenger cars to total cars indicating the percentage of the number of gas cars purchased each year in relation to all other fuelled passenger cars [42].

\subsection{Biogas Flow in the Regional Value Chain}

The region has a good biogas potential ( $313 \mathrm{GWh}$ ) based on local feedstocks (food waste, sewage sludge, manure, food industry waste, industrial waste (including slaughter waste) and energy crops) [20]. Looking at the gas flow (e.g., in terms of energy) through all segments along the value chain in the region, there is a big gap between theoretical potential and practical use. Just around 7.6 percent $(24 \mathrm{GWh})$ of the existing potential is utilised. From 2010 to 2018 , around $40-60 \%$ of produced biogas has been upgraded while the rest is used for heat and power production (The internal use of biogas and wastewater treatment plants is included). Due to lower market demand as transport fuel between the same periods, around $70 \%$ of the upgraded biogas has been used as transport fuel while $30 \%$ either flared or used in industry (Figure 6). However, with the introduction of new biogas busses in 2019-2020, almost all upgraded biogas in the region is used as a transport fuel. Still, besides the additional potential, a large part of raw biogas produced in the region is not upgraded (Figure 6). There could be several causes of this poor biogas development situation in the region, but some important ones are listed in the coming section.

In summary, this statistical analysis shows that biogas development in the region started very late compared to the rest of Sweden, (Still, there could be some regions in Sweden such as Dalarna, Västerbotten, where biogas development situation might be not good as Gävleborg. Nevertheless, in this article we consider average development in the rest of Sweden.) and has been very slow until 2017 in all segments of the value chain. Sewage sludge and food waste are feedstock types used for biogas production in the region where sewage sludge was, and still is, a dominant feedstock. Until 2018, the regional biogas producers have had no interest in introducing other feedstocks (e.g., manure, and industrial and agricultural residues, etc.) to the biogas production system although the feedstocks are successfully in use for biogas production in many other regions in Sweden. The lower market demand in the past decade and uncertain future demand were the main causes of less interest of the regional biogas producers in the further development of the system. However, based on increased demand for upgraded biogas in public transportation the horse manure was introduced in 2019 as a new feedstock to the Forsbacka biogas plant. 


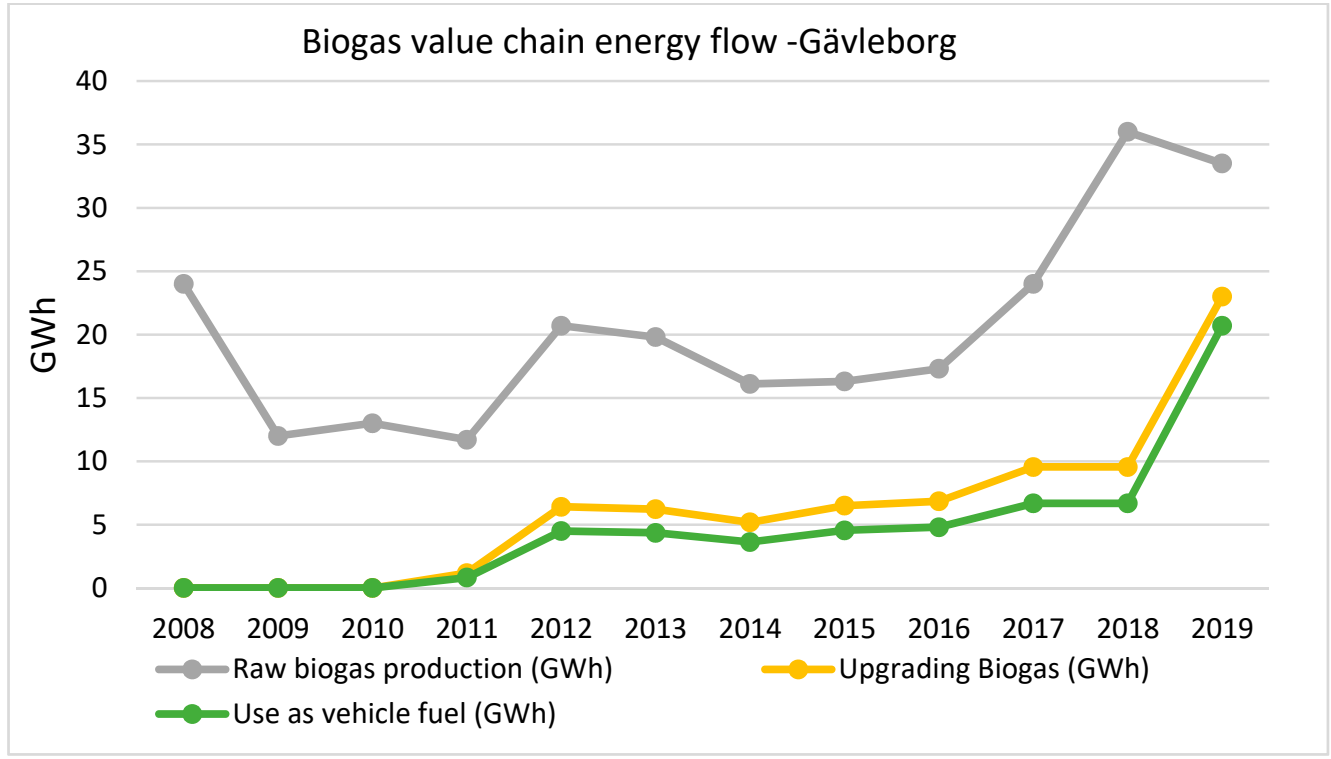

Figure 6. Biogas as energy flow in the value chain-Gävleborg.

\section{Constraint Factors for Biogas Development}

\subsection{Rules of the Game (Exchange of Services)}

Municipalities are important entities in local policy and development strategy formulation and implementation. Their role is crucial as they are found in all parts of the value chain from feedstock to gas use. For the Forsbacka biogas plant, source-separated household organic waste is the main feedstock but municipalities in the northern part of the region have not yet implemented source separation of food waste. The implementation of source separation and delivery of organic waste to Forsbacka biogas plant is considered as an extra cost, making the municipalities demand upgraded biogas in return which also relies on the building of gas filling stations. The gas company (Ekogas AB) does not see incentives in investing in setting up vehicle gas filling stations in those municipalities, as they do not have biogas vehicles. In response to this, the municipalities do not want to make any procurement decisions before they were ensured of continued supply of biogas and filling stations by the gas producing companies. Gasum (Gasum is one of the leading Nordic biogas producers and suppliers and owns 48 gas filling stations in Sweden ( 21 for heavy duty and 27 for passenger cars). The company has received permission to build gas filling stations in Gävleborg (www.gasum.se, (accessed on 14 April 2021))) is in a similar situation where the company has to come to an agreement with regional authorities and biogas producers on biogas supply conditions at their filling stations in the region. The company is more interested in supplying their own produced biogas instead of the biogas produced in the region (based on the interview with Gasum) and vice versa. This unclear situation on exchange of services "rules of the game" is one of the barriers to local biogas development (This is Mostly based on interviews with actors in the feedstock and biogas production segments).

\subsection{Municipalities Prioritization, and Decisions}

In the region, several options for different fuels of road transport exist. Parallel efforts are being made on the development and use of hydrogen, biogas, forest-based biofuels (i.e., biodiesel and bio-gasoline) and electricity for road transport. All these fuels are promoted locally, and biogas producers are facing tough competition due to the small size of the market. These alternate fuel transport systems (i.e., fuel production and vehicle technologies and infrastructure) are in the early phases of their development and have their pros and cons from a regional geodemographic perspective. As a result, two conventional fuel solution (petrol and diesel) will become a multi-fuel solution where each fuel will take 
its relevant place in the system. However, municipalities are reluctant in prioritising and taking the decision on which transport system (i.e., fuel and vehicle technology) they should choose (based on interviews with production and use segments actors); this ambiguity has been and still is one of the main factors for the slow biogas development in the region.

\subsection{Regional Culture}

The Gävleborg region as a whole is characterised by special conditions for entrepreneurship, i.e., a large number of small companies tend to have strong local anchors rather than have interests in business expanding or participation in sustainable development. It is also known that there is statistically relatively higher unemployment and lower level of education within this region as compared to the rest of Sweden (Swedish national statistics database (SCB)). Educational attainment of the population (see excel file. Source: www.scb.se (accessed on 14 April 2021)). A low level of education has been pointed out as one of the significant socio-cultural barriers to a lift of biogas development [43]. This can be understood that a low level of knowledge of the general population leads to a lack of awareness and acceptance about the importance of biogas as a renewable fuel alternative. As a matter of fact, the county of Gävleborg constitutes two parts, the landscapes of Gästrikland (southern part) and Hälsingland (northern part) that are quite different in terms of social culture, norms, and topography. People in the northern part has a lower level of education compared to the southern part of the region. For instance, the latest statistics suggest that the southern part has a higher number of registered students in high school per 1000 inhabitants [44]. Although both parts are well connected to the developed road infrastructure, different social norms act as a blocking mechanism in developing a comprehensive long-term strategy on biogas as a transport fuel for the whole region (based on interviews with the feedstock segment actors).

\subsection{Policy Issues}

Municipal governments in Sweden manage most of the fiscal resources, perform planning, make strategies, and take decisions based on local conditions. Private and public companies in a region usually follow regional political directions and policies. Whereas regional politics are the bodies that implement a national vision. In Gävleborg, the biogas infrastructure is poorly developed so that national directions have been impossible to live up to for the regional authorities. This has been a contradictory point regarding consensus among the region's municipalities on setting the biogas sector as an important player in the regional sustainable transport vision.

Several biofuel development policy instruments such as the local climate investment program KLIMP and the rural development program were aimed to benefit more climate change mitigation projects in rural areas of Sweden. The measures enabled municipalities and other local actors in the renewable energy field to receive financial support for projects that reduce GHG emissions. Based on interviews with production and use segments of the value chain (See Table 1), the effects were not as intended and counties with a demographic and political situation similar to Gävleborg could not take as much advantage as some other counties (e.g., Skåne, Stockholm, and Västra Götaland) in Sweden. In Gävleborg, the projects (Biogas MellanNorrland (Biogas i Mellannorrland) AB owned by three municipalities [Sundsvall, Östersund, and Hudiksvall]. Hudiksvall is a municipality of Gävleborg Region. [https:/ / sundsvall.se/kommun-och-politik/overklaga-beslut-rattssakerhet/motenoch-protokoll/bolag-och-forbund/biogas-mellannorrland-ab/], (accessed on 20 January 2020) and SETA) received grants through the programs but could not succeed. Higher production cost and lower GHG emission reduction efficiencies due to large distances between feedstock sources such as dairy farms and proposed production facility were the main reasons of failure of the projects. These lower GHG reduction efficiency and energy balance are parameters used by the authorities (such as Swedish environmental and energy agencies), to some extent, to claim that the policy is efficient. Therefore, in an "efficient policy perspective" there will be no grants for regions like Gävleborg. This implies that more support 
must be added from another body such as municipalities or private companies, and, if they are relatively small in size, biogas is a "luxury" they cannot afford. In short, national biofuel instruments and other biogas programs (e.g., regulatory, financial, and economic) have not played much of a role, particularly in promoting biogas as a transport fuel in the region (actors in the whole value chain).

\subsection{Lack of Network}

Networks play an important role in a technological system expanse and development as they help in the transfer of knowledge, create legitimacy, and influence the political goals by people having similar ideas, beliefs, etc. [45]. The political environment in the region was not in favour of biogas at times when several national investment programs on biofuels (Table 1) were announced. The important factors behind the situation were insufficient knowledge on biogas potential, available resources, and other supporting assets (i.e., financial and technical support), its economic and social implications and very weak pro-biogas social and other related organizations' movements. This can be attributed to a lack of proper communication and marketing between the actors and politicians supporting biogas. This is assumed as a big barrier to early biogas development in the region (mainly based on interview with Biodrivmitt and some actors in the use segment).

\subsection{The Dilemma of Lack of Infrastructure and Market}

Which should come first, filling stations or biogas vehicles? Some of the actors interviewed assumed that the municipalities' role is crucial in this case as they are big suppliers of substrate and buyers of upgraded biogas. They can create a market through public transport and force biogas producers, suppliers, to build related infrastructure. The dilemma is that the public transport service providers and other private companies such as taxi companies in the region were not willing to invest in biogas vehicles before the biogas supply infrastructure is securely in place. On the other side, biogas producers would like to have a biogas market first. This has been a dilemma in the region for a long time, which has slowed down the biogas development (actors in production and use segments). In 2011, an effort was done by Gävle Energi AB to solve this issue by first building the filling station and supported it with imported gas from outside the region (Stockholm). A year later, the upgrading facility at Duvbacken was inaugurated. However, some years later the opposite problem arrived when new production capacity was not followed by increased demand and the implication of cheap Danish biogas ruined the possibility to "export" the upgraded biogas to the greater Stockholm area.

All interviewed actors mentioned the insufficient number of filling stations in the region as an important barrier to biogas development in the past and present. The infrastructure development companies such as Ekogas AB and Gasum AB have pointed out that the permit process to build related infrastructure is very slow which has further delayed the development in addition to the dilemma on infrastructure and market. This problem has also been identified as a barrier to biogas development in Sweden by many authors (see, Introduction). The actors in the used segment strongly mentioned the effects of this cause as the regional transport companies and even private persons in the region have not considered the green car rebate and other schemes in their procurement decisions (based on the transport companies in the county).

\subsection{Public Transport as Focused User}

Some actors assumed that too much focus on public transport as a consumer of biogas and non-proactive marketing and long-term planning attitude of the regional biogas producers as causes for insufficient biogas infrastructure in the region. Most of the Swedish municipalities have used the public procurement instrument as a tool to convince companies that are owned by local governments or operating in the sectors of waste management, energy, and public transport, to use renewable fuels such as biogas to fulfil political ambitions concerning energy and climate matters $[7,11,33]$. This tactic 
has been used as a powerful tool by the Gävle municipality to create an early biogas market in the region. The actors further mentioned that the biogas producers in the region have not been active in creating a market (i.e., by delivering information and signing contracts with private transport companies in the region) at the initial stage of a project (i.e., the building of a biogas plant). This resulted in a limited market due to the lower number of biogas vehicles which slowed the biogas development in the region (based on interview with BiodrivMitt and transport companies).

\section{Lessons Learnt and Recommendations for Improvement}

Government support schemes are vital for further biogas development and should be designed in a way that can integrate local factors in grant evaluation criteria and reduce risks on investment with clarity on future market conditions of the fuel. For example, in the project evaluation process the system benefits of fuel, fertiliser, and waste treatment that are shared among many actors and the whole of society, should also weigh with GHG reduction potential and net energy balance. The regions with similar geodemographic conditions should consider system benefits as a basis for their decisions rather than the conventional cost of alternate transport technologies.

In a situation where multiple solutions to a problem exist with their own limitations and opportunities, ad hoc events can occur. The situation is the same in Gävleborg on sustainable energy solutions for transport. The regional municipalities are weighing the alternate transport energy solutions for their best interests so that they invest public money efficiently. The municipalities should come out of this ambiguous situation with the help of the relevant experts (e.g., academic researchers) to build consensus on what part of the transport sector (i.e., heavy trucks, public transport, passenger cars, etc.) should be directed to biogas and to other fuels. This will make it easier for them to find out at which segment of the biogas value chain they should invest, with whom, and on what terms. One possible solution for further development of the regional biogas sector could be public transport in all the regional municipalities include biogas buses to secure the gas market and maximise the use of upgraded biogas.

Regional transport system actors are promoting alternate renewable fuels (hydrogen, bio-oil from forest biomass, and HVO) but the alternate fuels developments are in their early phases of development in the region. The actors belong to different technological development routes should learn from the biogas case to prepare in advance to avoid the issues that the regional biogas sector had, and is still, facing. Simultaneously, there is a need for the biogas sector to collaborate with others to increase the development by learning, knowledge sharing, and better communication among the regional municipalities and other biofuel value chain actors and networks.

Waste management and nutrient circularity aspects are the benefits that make biogas an opportunity to expand and develop. Therefore, apart from sewage sludge and food waste, regional biogas producers should also focus on introducing diverse kind of feedstocks such as agricultural residues, pulp and paper mill residues, and animal manure to increase biogas production and maximise the biogas system benefits to society.

The anaerobic digestion process for biogas production is mature and well-established. From economic and operations control perspective, the technology is applicable to smalland commercial scales but upgrading biogas is costly both from a technology and operations perspective. In the region, around $40-50 \%$ of produced biogas is not upgraded due to higher cost. Incentives should be introduced to promote R\&D for innovative technological solutions to biogas upgrading. This might be difficult for the regions but probably could be managed at national and EU-regional levels. Innovative cost-effective upgrading technology for small-scale biogas plants can help a lot to improve the economic situation of the biogas sector and market conditions in such counties.

In addition to infrastructure, the security of biogas supply for a long time has been highly important for transport companies. The actors proposed that, for continued expansion of biogas as a transport fuel in the region, required infrastructure should be built first 
by the gas producers and suppliers. The municipalities should play their role in this case either through subsidizing and/or making the permit process fast. To ensure the security of gas supply a gas grid/terminal in the region may also be required. These actions can strengthen the user's confidence and boost the market. Moreover, a higher discount on gas vehicles, carbon, and energy tax exemption for biogas, as transport fuel should continue and for a long time. The biogas sector could face tough challenges in the future due to fast development in alternate green energy technologies such as hydrogen and fuel cells, biodiesel, electrification etc., and changing political views on electrifying public transport. Thus, it may not be right to focus on building a gas market for cars and public transport only. Heavy-duty transport, shipping and industry should be prioritised in future biogas strategy as potential users. In the short run, public sector organizations should use their procurement strength to support the biogas sector and other green fuels as well. Further, looking to the shipping industry as an alternate future user for upgraded gas is good for the regional biogas sector as the region has a harbour.

\section{Conclusions and Outlook}

The interviews and statistical analysis of value chain development resulted in a great deal of relevant information. Largely, the respondents, not all, on the production, supply, distribution, and use segments provided a similar picture, and there appears to be a consensus regarding many local issues influencing the biogas development, even if there could be some limitations in their generalization and validity in similar cases.

In the region, biogas can play an important role in establishing a strong socio-technical system providing transport services of different kinds but lacks a long-term development strategy. From a biogas potential standpoint, statistical analysis shows that the amount of biogas could increase significantly within the region, but expansion and development for biogas as transport fuel started very late and have been very slow compared to the rest of Sweden. This is mostly caused by local factors, explained above (Section 5), and to some extent by policy design which lacks integration capability of geodemographic conditions and system benefits. The interviewees reflected a similar picture. The additional issues with national policy measures are linked to investment cost, infrastructure, and market demand. These national policy-related and local factors as barriers to the biogas developments: lack of consensus among the regional municipalities on biogas as a transport fuel, poor communication and weak network of regional biogas producers, users and legislators, and insufficient knowledge of the actors on regional biogas potential and its socio-economic implications, etc., reported by similar studies (e.g., $[5,7,17,46])$ on other regions of Sweden, see the introduction section, are also confirmed. Additionally, this study identifies some additional regional factors influencing biogas development which are worth mentioning and not have been previously reported in detail; these are undefined rules of the game (exchange of services), competition among several alternatives due to a small market, as well as the ambiguity of municipalities prioritization, and regional cultural differences (Section 5).

To strengthen the regional biogas sector and expansion, national policy instruments should provide mechanisms that can process geographical conditions in regulatory, economic support, and market formation, e.g., in the evaluation process for granting incentives. The building of gas filling stations at other municipalities and long-term contracts between biogas producers and buyers are needed to expand the system. An active network of biofuel producers, users, and legislators is vital in the region to speed up the development by learning, knowledge sharing, legitimation, and better communication. Furthermore, the biogas value chain actors' knowledge about the regional resources/feedstocks suitable for biogas production and their techno-economic analysis are very important for the future development strategy of the sector. In short, at the local level, suitable measures should be taken by the system actors to eliminate the blocking effects of identified local factors and for the continued development of the regional biogas value chain. 
Author Contributions: M.A. collected the data, designed methodology, and performed value chain analysis. Z.W. and S.S. contributed to conceptualization, data collection, supervision, and contributed in writing-review and editing. Project administration, O.E.; funding acquisition, O.E. and contributed in writing - review and editing. All authors have read and agreed to the published version of the manuscript.

Funding: The European Regional Development Fund of the European Union, Region Gävleborg and the University of Gävle, project number 7441, funded this research.

Data Availability Statement: Not applicable.

Acknowledgments: This work has been carried out within the project RATT-X, (Regional Alternative Technologies for the Traffic in Gävleborg region) project no. 7441. We are thankful to Karl Hillman, Associate Professor at the University of Gävle for providing important literature, latest news articles, and intellectual discussions when the manuscript was in the preparation phase. The authors also gratefully acknowledge all the reviewers for their constructive comments. The authors would also like to thank all the regional biogas value chain actors who participated in the interview process.

Conflicts of Interest: The authors declare no conflict of interest.

\section{Appendix A}

Table A1. Organizations involved in the study, their roles and information about respondents. This article mainly focused on regional organizations that are linked to the biogas value chain and organizations that have influenced or can influence the value chain. Note: All interviews were recorded, analysed, and summarised in the text.

\begin{tabular}{|c|c|c|}
\hline Value Chain & Organization & Description of the Organization and Interviewee \\
\hline Feedstock & $\begin{array}{c}\text { The Federation of Swedish } \\
\text { Farmers (Lantbrukarnas } \\
\text { Riksförbund) }\end{array}$ & $\begin{array}{l}\text { Waste management company owned by five municipalities in } \\
\text { the region of Gävleborg (Gävle, Sandviken, Hofors, Ockelbo } \\
\text { and Söderhamn). The company is part owner of Ekogas (see } \\
\text { below). It collects biological waste from these five } \\
\text { municipalities and delivers to the Forsbacka biogas plant. } \\
\text { Respondent: CEO. } \\
\text { Waste management company owned by two municipalities } \\
\text { (Bollnäs and Ovanåker). The company operates the waste } \\
\text { facility at Sävstaås in Bollnäs, as well as the recycling centres in } \\
\text { Bollnäs and Edsbyn. Respondent: CEO. } \\
\text { Wastewater treatment company owned by three municipalities } \\
\text { (Gävle, Hofors, and Ockelbo) which operate } 15 \text { wastewater } \\
\text { treatment plants in the region. The biggest plant in Gävle has a } \\
\text { capacity of up to 100,000 people's equivalent (pe) and produces } \\
\text { and upgrades biogas from sludge. The upgrading unit at this } \\
\text { facility is owned and operated by Ekogas (see below). } \\
\text { Respondent: Process Engineer. } \\
\text { The company is involved in multiple businesses, waste and } \\
\text { wastewater treatment and management, electricity and heat } \\
\text { production and supply. It is owned by Söderhamn municipality. } \\
\text { It collects biological waste from three municipalities } \\
\text { (Söderhamn, Bollnäs and Hudiksvall) and transports it to the } \\
\text { Forsbacka biogas plant. Respondent: Waste collection manager. } \\
\text { The regional branch of the Federation of Swedish Farmers is an } \\
\text { agricultural interest organization. Interview regarding } \\
\text { possibilities for and perception of biogas among Swedish } \\
\text { farmers. Respondent: Regional manager. }\end{array}$ \\
\hline
\end{tabular}


Table A1. Cont.

\begin{tabular}{|c|c|c|}
\hline Value Chain & Organization & Description of the Organization and Interviewee \\
\hline Production and upgrading & Gästrike vatten & $\begin{array}{l}\text { The only company in the region that has industrial-scale biogas } \\
\text { production with an upgrading facility is partly owned by the } \\
\text { municipality. Feedstocks used are food waste, green waste, and } \\
\text { wastewater sludge. The company facility at Forsbacka is based } \\
\text { on dry anaerobic digestion technology and produces around } \\
6-7 \text { thousand Nm3 raw biogas per day with } 55-60 \% \text { methane } \\
\text { content. On average, this is } 2.3 \text { million Nm3 per year. The gas is } \\
\text { upgraded to } 97-99 \% \text { CH4 content. The company owns and is } \\
\text { responsible for a biogas upgrading plant at Duvbacken } \\
\text { wastewater treatment plant (owned by Gästrike vatten). } \\
\text { Respondent: Chief Operating Officer. } \\
\text { See above. }\end{array}$ \\
\hline
\end{tabular}

Ekogas

Infrastructure

Gasum
Regional Administrative Board (Länsstyrelsen)

Use as vehicle fuel

The region has two biogas filling stations owned by this company. Two to three more filling stations by 2021 are in planning by the company. Respondent: Chief Operating Officer. Gasum is one of the leading Nordic biogas producers and suppliers. It owns a gas filling-station network, which also serves heavy-duty vehicles. The company supplies both CBG and LBG and is a big player in the Nordic market. The company has no gas production in the region while it has got permits to build gas filling stations both for liquefied and compressed bio-methane in the region. Respondent: Traffic Business Development Director.

\section{Entrepreneurs organization (Företagarna)}

\section{Gävle Taxi}

Region Gävleborg

X-trafik
The organization represents about 60,000 entrepreneurs through 250 local associations in Sweden. It offers networks, knowledge, and practical help, and drives the development for a better business climate. The regional office of the organization is in Gävle. Respondent: Regional Business Analyst. One of the oldest and leading taxi companies with 60 vehicles. Mainly operates in the cities of Gävle and Sandviken. The company is fossil-free with all vehicles on $100 \%$ HVO. Respondent: Regional Manager.

The regional administrative board works to ensure national policies are implemented and targets are being achieved while taking into account local conditions and circumstances. It also monitors developments and informs the government of the region's needs. The board is an important link between people and municipalities in the region on the one hand and the government, parliament, and central authorities on the other. Respondent: Agronomist, climate, and energy coordinator. A public organization, where the regional council is the highest decision-making body. The organization is responsible for areas that contribute to regional development. The main areas of management and responsibility are public health and health care, infrastructure and public transport, skills and education issues, business development, international co-operation, and culture. Respondents: Project manager and strategist, Project leader (environment and strategy), and Strategist sustainable development.

An authority, responsible for regional transport services as part of Region Gävleborg. The authority does not own any buses or trains but acts as a decision-maker and is responsible for public transport strategy, functions, and development. It is also involved in the procurement of vehicles and services outside public transport as well. Respondent: Project Manager and strategist. 


\section{Appendix B}

Sample Interview questions for each segment of the biogas value chain. The questions were adjusted to the interests of the interviewee and there have been follow-up questions based on the response of the interviewee to the main question.

\section{General questions}

1. Can you speak briefly about yourself, the company/organization and its activities concerning biogas a transport fuel in the region?

2. How can immigrants participate at the organisation/company and biogas system levels, in relation to the work with sustainable transport?

\section{Feedstock}

1. What types of waste/feedstock is delivered to biogas producers and the source?

2. How do municipalities work with the waste management companies and how many they are in the region?

3. How good the waste/feedstock is source sorted? How can it be improved?

4. What happened with the collected biological waste? Is it used to produce biogas?

5. How do you see the importance of collaboration between the regional waste management companies, agricultural sector, and renewable fuels (e.g., biogas and bio-diesel) producers? And, what could be done to improve the situation?

6. What are the opportunities and challenges for regional agricultural SMEs and municipalities with providing biological waste/substrates for biofuels production?

7. What kind of legislative, financial, and R\&D support, you think, would require to promote the use of regional agricultural and other biological resources for biogas production?

8. Which type of biological waste is being imported to other regions and why?

9. What are the key challenges the company is facing? What and how regulations/standards/ policy can help with?

\section{Production and Upgrading}

1. What technology and feedstocks are used for biogas production?

2. What are the sources of feedstocks?

3. How much biogas is produced, upgraded, and delivered to biogas filling stations?

4. How do you see the future of biogas in a regional context?

5. What are the key challenges for biogas producers in this region?

6. What and how national biofuel related policy instruments have been supporting/ influenced biogas development in the region?

7. How regional politics/cultural believes/geographic conditions influenced biogas development in the region?

8. What needs to do for further expansion of biogas as a transport fuel in the region?

\section{Infrastructure}

1. Why infrastructure (filling stations) poorly developed?

2. How do you see the role of national biofuel policy instruments in this context?

3. How can the situation be improved? Who has to do what?

4. How you relate regional biogas market (demand) as transport fuel and infrastructure conditions?

\section{Use}

1. What percentage of vehicles are biogas fuelled?

2. Why/why not biogas as transport fuel?

3. How are national biofuels policy instruments (e.g., biogas vehicle rebate program) evaluated in vehicles procurement decisions?

4. What needs to do for increased use of biogas as a transport fuel in the region?

\section{Regulative actors (Municipalities and regional authorities)}

1. Why the Gävleborg should have biogas as transport fuel?

2. How do you predict the future of biogas in the region? 
3. How have the regional authorities supported biogas as a transport fuel in the region?

4. What can the regional authorities and municipalities do for the further expansion of biogas as transport fuel?

5. How do you value the national biofuels policy instruments for biogas as transport fuel development in the region?

\section{References}

1. Lönnqvist, T.; Ammenberg, J.; Grönkvist, S.; Anderberg, S.; Sandberg, T. Biogas in the Transport Sector-An Actor and Policy Analysis of the Stockholm County; (Report No 2019:02); The Swedish Knowledge Centre for Renewable Transportation Fuels (f3 centre): Stockholm, Sweden, 2019.

2. Swedish EPA. Sweden's Climate Act and Climate Policy Framework. Available online: http://www.swedishepa.se/ Environmental-objectives-and-cooperation/Swedish-environmental-work/Work-areas/Climate/Climate-Act-and-Climatepolicy-framework-/ (accessed on 20 January 2020).

3. Ros, T.; Ödlund, L. System perspective on biogas use for transport and electricity production. Energies 2019, 44, 27-28. [CrossRef]

4. Feiz, R.; Ammenberg, J. Assessment of feedstocks for biogas production, part I-A multi-criteria approach. Resour. Conserv. Recycl. 2017, 122, 373-387. [CrossRef]

5. Fallde, M.; Eklund, M. Towards a sustainable socio-technical system of biogas for transport: The case of the city of Linköping in Sweden. J. Clean. Prod. 2014, 98, 17-28. [CrossRef]

6. Hjalmarsson, L. Biogas as a boundary object for policy integration-The case of Stockholm. J. Clean. Prod. 2015, 98, 185-193. [CrossRef]

7. Ammenberg, J.; Anderberg, S.; Lönnqvist, T.; Grönkvist, S.; Sandberg, T. Biogas in the transport sector-Actor and policy analysis focusing on the demand side in the Stockholm region. Resour. Conserv. Recycl. 2018, 129, 70-80. [CrossRef]

8. Eker, S.; van Daalen, E. A model-based analysis of biomethane production in the Netherlands and the effectiveness of the subsidization policy under uncertainty. Energy Policy 2015, 82, 178-196. [CrossRef]

9. Goulding, D.; Gallagher, C.; Power, N.M. What policies should be implemented to develop a gaseous transport industry in Ireland? Env. Sci. Policy 2014, 44, 215-225. [CrossRef]

10. Lantz, M.; Svensson, M.; Björnsson, L.; Börjesson, P. The prospects for an expansion of biogas systems in Sweden-Incentives, barriers and potentials. Energy Policy 2007, 35, 1830-1843. [CrossRef]

11. Larsson, M.; Grönkvist, S.; Per, A. Upgraded biogas for transport in Sweden- effects of policy instruments on production, infrastructure deployment and vehicle sales. J. Clean. Prod. 2016, 112, 3774-3784. [CrossRef]

12. Uusitalo, V.; Havukainen, J.; Soukka, R.; Väisänen, S.; Havukainen, M.; Luoranen, M. Systematic approach for recognizing limiting factors for growth of biomethane use in transportation sector-A case study in Finland. Renew. Energy 2015, 80, 479-488. [CrossRef]

13. Olsson, L.; Fallde, M. Waste(d) potential: A socio-technical analysis of biogas production and use in Sweden. J. Clean. Prod. 2015. [CrossRef]

14. Browne, D.; O'Mahony, M.; Caulfield, B. How should barriers to alternative fuels and vehicles be classified and potential policies to promote innovative technologies be evaluated? J. Clean. Prod. 2012, 35, 140-151. [CrossRef]

15. Steenberghen, T.; López, E. Overcoming barriers to the implementation of alternative fuels for road transport in Europe. J. Clean. Prod. 2008, 16, 577-590. [CrossRef]

16. Mutter, A. Obduracy and change in urban transport-understanding competition between sustainable fuels in swedish municipalities. Sustainability 2019, 11, 6092. [CrossRef]

17. Lönnqvist, T.; Anderberg, S.; Ammenberg, J.; Sandberg, T.; Grönkvist, S. Stimulating biogas in the transport sector in a Swedish region-An actor and policy analysis with supply side focus. Renew. Sustain. Energy Rev. 2019, 113, 109-269. [CrossRef]

18. Lönnqvist, T.; Sanches-Pereira, A.; Sandberg, T. Biogas potential for sustainable transport-A Swedish regional case. J. Clean. Prod. 2015, 108, 1-10. [CrossRef]

19. Gustafsson, S.; Mignon, I. Municipalities as intermediaries for the design and local implementation of climate visions. Eur. Plan. Stud. 2019, 28, 1161-1182. [CrossRef]

20. Arfan, M. Biogas Value Chain in Gävleborg_Feedstock, Production and Use; University of Gävle: Gävle, Sweden, 2019.

21. Kaplinsky, R. Globalisation and unequalisation: What can be learned from value chain analysis? J. Dev. Stud. 2000, 37, 117-146. [CrossRef]

22. Owen, G.T. Qualitative methods in higher education policy analysis: Using interviews and document analysis. Qual. Rep. 2014, $19,1-19$.

23. EEA. National Policies and Measures on Climate Change Mitigation in Europe in 2017: Technical Overview of the Information Reported by Member States Under the European Union's Climate Monitoring Mechanism Regulation; (EEA Report No. 9/2018); EEA: Copenhagen, Denmark, 2018.

24. Fagerström, A.; Anderson, S. The Contribution of Advanced Renewable Transport. Fuels to Transport Decarbonization in Sweden-2030 and Beyond; (Report No.C416); IVL Swedish Environmental Research Institute: Stockholm, Sweden, 2019.

25. Government of Sweden. Report for Sweden on Assessment of Projected Progress, March 2019; Government of Sweden: Stockholm, Sweden, 2019. 
26. Holmgren, K. Policies Promoting Biofuels in Sweden; (Report f3 2012:3); The Swedish Knowledge Centre for Renewable Transportation Fuels f3: Gothenburg, Sweden, 2012.

27. The Swedish Parliament. Swedish Code of Statutes (1994). Act on Energy Taxes; The Swedish Parliament: Stockholm, Sweden, 1994. (in Swedish)

28. The Swedish Parliament. Swedish Code of Statutes (2006). Act on Road Traffic Taxes; The Swedish Parliament: Stockholm, Sweden, 2006. (in Swedish)

29. Lantz, M. Biogas in Sweden: Opportunities and Challenges from a Systems Perspective; Lund University: Lund, Sweden, 2013.

30. The Swedish Parliament. Swedish Code of Statutes (2001). Regulation (2001:512) on Landfill of Waste (Förordning (2001:512) om deponering av avfall).pdf; Environmental Department: Stockholm, Sweden, 2001.

31. The Swedish Parliament. Swedish Code of Statutes (2005). Act on Obligation to Provide Renewable Fuel; SFS 2005:1248.pdf; The Swedish Parliament: Stockholm, Sweden, 2005. (in Swedish)

32. The Swedish Parliament. Swedish Code of Statutes (2009). Act on Support for Measures on Production, Distribution and Use of Biogas and Other Renewable Gases; SFS 2009:938.pdf; The Swedish Parliament: Stockholm, Sweden, 2009. (in Swedish)

33. SEPA. Green Public Procurement in Sweden; SEPA: Stockholm, Sweden, 2009.

34. Johansson, T.B.; Kågesson, P.; Johansson, H.; Jonsson, L.; Westin, J.; Hejenstedt, H.; Hådell, O.; Holmgren, K.; Wollin, P. On the Road to Fossil-Free Transport (in Swedish: Fossilfrihet på väg-Del 2); Ministry of Enterprise: Stockholm, Sweden, 2013 ; ISBN 9789138240557.

35. SEPA. Climate Investment Programmes in Sweden-A Tool for Reaching the Swedish Climate Objective; SEPA: Stockholm, Sweden, 2008.

36. Kalhori, E. Rätt Väg Framåt! En Sammanfattning av Klimatpolitiska Rådets Rapport 2019 (Report 1-2019); Swedish Climate Policy Council: Stockholm, Sweden, 2019.

37. Government of Sweden. Rural Development Programme for Sweden-Period 2007-2013; Government of Sweden: Stockholm, Sweden, 2013.

38. Government of Sweden. Fact. Sheet-A Rural Development Programme for Sweden, 2014-2020; Government of Sweden: Stockholm, Sweden, 2015.

39. Government of Sweden. Sweden's Draft Integrated National Energy and Climate Plan; Government of Sweden: Stockholm, Sweden, 2018.

40. The Swedish Parliament. Swedish Code of Statutes (2009). Regulation (2009: 211) on Environmental Cars; The Swedish Parliament: Stockholm, Sweden, 2009. (in Swedish)

41. The Swedish Parliament. The Act on the Obligation to Supply Renewable Fuels—A Follow-Up Report (2009/10:RFR7); The Swedish Parliament: Stockholm, Sweden, 2009.

42. Swedish Energy Agency (SEA). Energy in Sweden, Facts and Figures 2021. Available online: http:/ / www.energimyndigheten. se/Statistik/Energibalans/?currentTab=1\#mainheading (accessed on 20 February 2021).

43. Nevzorova, T.; Kutcherov, V. Barriers to the wider implementation of biogas as a source of energy: A state-of-the-art review. Energy Strat. Rev. 2019, 26, 100414. [CrossRef]

44. Region Gävleborg. Gävleborgare i utbildning 2019; Region Gävleborg: Gävle, Sweden, 2019.

45. Bergek, A.; Jacobsson, S.; Carlsson, B.; Lindmark, S.; Rickne, A. Analyzing the functional dynamics of technological innovation systems: A scheme of analysis. Res. Policy 2008, 37, 407-429. [CrossRef]

46. Lönnqvist, T. Biogas in Swedish Transport—A Policy-Driven Systemic Transition; KTH—Royal Institute of Technology: Stockholm, Sweden, 2017. 